\title{
Communication, global justice and the moral economy
}

- Andrew Calabrese

University of Colorado, USA

\begin{abstract}
The concept of a 'moral economy,' used famously by historian Edward Thompson in his 1971 essay, 'The Moral Economy of the English Crowd in the Eighteenth Century,' is sometimes invoked in discussions of struggles for social justice. Drawing from Thompson and others who have written about the idea of a 'moral economy,' this article shows how that concept serves as an instructive guide for thinking today about the idea of a global civil society and the global justice movement. Relying on historical work about selected struggles for social justice, this article demonstrates how the means of communication have been vital to transnational social movements for far longer than generally is acknowledged. Moreover, the means of communication have been central to sustaining the idea of a moral economy.
\end{abstract}

KEY WORDS

civil society - communication - globalization - justice - moral economy WSIS

We are in the midst of a decades-long assault on social rights at the national level, alongside concurrent efforts to expand corporate property rights transnationally. It is a rights revolution in progress, but there also is an accompanying counter-revolution, reflected by considerable resolve across a variety of social movements - labor, environmental, human rights, and others - to resist particular patterns of global economic development that are seen as threats to national sovereignty, and to the continued viability of social citizenship rights within national contexts (Arrighi et al., 1989; Amin et al., 1990). The pattern of globalization to which activists are opposed is one in which the prerogatives of 'global citizenship' seem to be evolving primarily to benefit mobile capital, manifested in the rights of the 'corporate person.' But alongside efforts to establish transnational corporate rights are efforts that aim to articulate

Global Media and Communication [1742-7665(2005)1:3] Volume 1(3): 301-315 
visions of a 'postnational' regime of social and cultural citizenship rights (Finer, 1999; Habermas, 2001). The broad range of aims found in this global movement are readily apparent in the World Social Forum, which is sometimes called 'the anti-Davos,' referring to the corporate-dominated World Economic Forum in Davos, Switzerland. Such aims also can be found in the efforts that have been underway to articulate a vision on behalf of the communication rights of 'civil society' in the World Summit on the Information Society (WSIS).

Much of the contemporary discourse about communication rights emphasizes the role of non-governmental and non-corporate stakeholders, sometimes referred to as 'civil society.' This term is used in an overall problematic way by communication rights activists, as illustrated by the 'Civil Society Declaration' that was presented in Geneva in 2003 during phase one of the WSIS. ${ }^{1}$ That document is generally understood by those who produced it to have been the result of cooperation across a broad rainbow coalition of identities, needs and interests. Despite this breadth, and whether or not it was the intention of those who drafted the Declaration, 'civil society' appeared to have spoken in one welltempered voice in Geneva. The Declaration embraces a definition of civil society that not only brackets out powerful private economic interests, it also assumes a certain moral position that excludes some of the nastinesses - racism, sexism, cruelty and exploitation of other kinds that others argue is intrinsic to actually existing civil society. In other words, then, the working concept of 'civil society' that is employed in multilateral forums of communication rights activists tends to be one that is rooted in moral idealism (Calabrese, 2004a).

My intention here is not to poke holes in such idealism, or to offer a realpolitik alternative for how diverse stakeholders should participate in multilateral forums. Despite widely voiced frustrations, one clear point of progress made at the WSIS in Geneva was that the range of legitimate participants in a significant global media governance forum was expanded well beyond vested corporate interests and governmental participants to include a wide range of voices calling for social justice. The diverse range of perspectives represented under the umbrella of 'civil society' in Geneva constituted in microcosm what is known as the global justice movement (DeMartino, 2000; De Grieff and Cronin, 2002). It is impossible to conceive of a global justice movement that does not recognize a central place for the means of communication as a source of both social ills and emancipation (De Jong et al., 2005). On the one hand, the institutions, technologies and policies that make up what we call 'the media' are tools in the aid of cultural commodification, 
excessive consumption, market censorship, political surveillance and the invasion of privacy. On the other hand, those same tools are means by which actors engaged in struggles for social justice are able to organize, coordinate and mobilize, as well as to bear witness to and bring to public shame the perpetrators of injustice. Consequently, and not surprisingly, the relationship between social movements and the means of communication is one of ambivalence over the intertwined repressive and emancipatory ends to which media development and use are put (Calabrese, 1999a). My aim below is to conceptualize the current global struggles over communication rights in terms of a moral economy. Communication is at the heart of the social justice movement that has emerged in response to the global liberalization of investment, production and trade. And struggles over communication rights are of necessity foundational, as both means and as ends in themselves, in any attempt to articulate the meaning of global justice.

\section{A rights revolution? The globalizing context of communication rights}

Contemporary uses of the idea of civil society tend to emphasize the empowerment of social actors through forms of association and activities that are not directly dependent on government or corporate control. In the United States, the idea is often linked to communitarian prescriptions aimed at shifting attention away from a preoccupation with rights and entitlements, and more towards norms of social responsibility (see, for example, Glendon and Blankenhorn, 1995; Etzioni, 1998). This way of thinking about civil society has also begun to travel widely throughout the world, via the influence of development agencies, World Bank initiatives, global NGOs, and governments seeking to emulate and embrace ideas that have currency in the global North, particularly the notions of 'self-help' and 'social capital,' achieved through strong ties of civic association. Communitarianism is a wideranging movement that distinguishes itself from liberalism, sometimes quite explicitly, especially by opposing the materialism and greed that is seen to underlie the neoliberal economic agenda. Among the intellectual legacies often cited by communitarian authors is the work of Alexis de Tocqueville, who argued that what made democracy in America work was civic virtue, cultivated through commitment and direct involvement in local community affairs. The critique of the welfare state by communitarians, and visions of alternatives, bear directly on the compelling language of 'empowerment,' 'virtue,' and 'obligation' that is 
used widely by communitarians who reject the 'culture of dependency' that the term 'welfare' has been made to signify (Mead, 1986). A principal concern among communitarian critics is that the welfare state draws upon the proceduralist orientation of liberal political philosophy, a philosophy that communitarians find lacking in any coherent moral conception of 'the good life' (Mulhall and Swift, 1996; Sandel, 1996).

Communitarians tend to lament the results of the 'rights revolution,' an expansion of individual and group rights that took place in the United States beginning with the Johnson administration's 'Great Society' initiatives of the 1960s, and coming to an end, beginning with the Carter administration and continuing steadily throughout the Reagan, Bush Sr, Clinton, and Bush Jr administrations (Walker, 1998). What was 'revolutionary' about this period was that recognition of structural forms of inequality and impoverishment increasingly became matters for which remedies were sought through legislation, regulation, and the courts. This revolution has been widely criticized by communitarian thinkers, who suggest that in the United States we have 'too many rights, too few responsibilities' (Etzioni, 1995). That position has been used to justify many arguments for dismantling the welfare state, and was most visible in the passage of the Welfare Reform Act by the Clinton administration. Similar, but typically less extreme, patterns of declining welfare states have obtained in a number of affluent countries (Teeple, 2000). Although communitarianism and neoliberalism are at odds in many ways, adherents of these two perspectives find common ground in that both tend to attack individual social rights (Calabrese, 1997). Neoliberal economic policies have aimed at the heart of a target that also lies in the sights of communitarians, which is policies that historically have been understood as the foundations of social citizenship (Marshall, 1950). Meanwhile, neoliberalism tends to edify expanded trade and investment rights for global corporations, particularly as such rights pertain to intellectual property, while communitarianism tends to remain conspicuously silent about this particular arena of rights expansionism. At the end of the day, contrary to the good intentions of its adherents, communitarian discourse has the unintended effect of serving as rhetorical nursemaid to neoliberalism. While blaming the victims of social and economic inequality, communitarians show no comparable level of concern about the moral deficiencies of unleashing corporate avarice through neoliberal policy making. ${ }^{2}$

The ideological framework of neoliberalism has been advanced in 
the United States for many years through the government's domestic and foreign media policy. In a 1983 speech by Mark Fowler, Chairman of the US Federal Communications Commission (FCC) during the Reagan administration, he referred to television as 'a toaster with pictures.' Fowler's point was that culture in general, including the media, should be given no special consideration or treatment by governments in comparison with other areas of commerce (Mayer, 1983). The logic behind this view is that governments should play no role in the shaping or nurturing of culture, and that it is the marketplace alone that should govern culture. Of course, it is not true that a government that responds to big corporate interests is one that necessarily favors a free and competitive marketplace. Rather, the de facto goal of some of the most significant recent deregulatory initiatives in the United States has been the greater concentration of ownership and a reduction in the number of independent voices (Calabrese, 2004b). The 'marketplace' view that has been advanced in US domestic media policy since the 1980s was consistent with the withdrawal of the United States from UNESCO, an organization that had become the locus of multilateral efforts to oppose allowing the discipline of the big media market to dominate cultural production and distribution. Despite the resistance that many countries have held towards submitting cultural practices to the discipline of market- (or neo-) liberal trade and investment policies, the United States has relentlessly pursued a foreign media policy that aims precisely at that outcome (Calabrese and Redal, 1995). Since the United States could not control the outcomes of UNESCO recommendations, and since UNESCO (through the MacBride Report) was recommending positions that ran counter to US ideological positions and economic interests, it made sense for the United States do as Secretary of State George Schultz stated, which was to pursue 'other means of cooperation' (Schultz, 1984: $82,84)$. Shultz may not have anticipated the exact ways in which such cooperation would be achieved, but US efforts to end the 'cultural exception' within the World Trade Organization (WTO) are clear evidence of a single-minded trajectory in US foreign media policy over the past 25 years, notwithstanding the seemingly incongruous recent reentry of the United States into UNESCO.

The decision by the United States to rejoin UNESCO should come as no surprise. Since 1984, UN leaders have worked assiduously to attract the United States back into the fold, even to the point of rejecting the organization's own past. Thérèse Paquet-Sévigny, UN Under-SecretaryGeneral for information in 1990, clearly articulated an anti-NWICO position that was consistent with US policy and official ideology: 
Over many years, the international debate on information and communication did not result in agreement on a common approach. I wish only to refer to some of the discussions, for instance, on concepts of a new world information order, which in the eyes of many actors in the field of communication have harmed international efforts to construct a world-wide information society. (quoted in Roach, 1997: 116)

The path to 'a world-wide information society' was not and is not something that has had to be constructed in a particular way, as this statement implies. But following the US withdrawal, UNESCO officials have tended to subordinate that organization's past pretenses to moral leadership to one of appeasement and conciliation, and in the process they embraced the official US vision of what a global information society should look like. For the US government, and for the governments of other affluent countries, the political task for the future has been one of engineering the 'creative destruction' of social welfare states and redirecting national policy efforts to build a neoliberal global information society (Calabrese, 1997, 1999a, 1999b). That task has been based on an intellectual shift in economic thought from Keynes to Hayek. UNESCO has conformed to that agenda by embracing, or at least not significantly opposing, a pro-WTO ideological framework, with its strong over-arching preoccupation with corporate intellectual property rights, as far as the idea of the global information society is concerned. Within this framework, not only has UNESCO lost much of its former moral authority as a deliberative forum about the place of culture in a just global order, but it also no longer poses a symbolic threat to the cultural norms of neoliberalism. By rejoining UNESCO, the United States can gain a modicum of symbolic capital with minimal sacrifice.

\section{Two conceptions of the moral economy}

A remarkable achievement of the contemporary global justice movement has been the demonstrated capacity of its diverse participants to draw worldwide attention to the causes they seek to address. For example, nongovernmental action often relies upon the practice of public shaming to hold institutions (governments, corporations) accountable to human rights norms that are sometimes endorsed in rhetoric but ignored in practice (Clark, 2001; see also Skeel, 2001). By many accounts, transnational civil society, a term generally used to refer to the diverse global collectivity of NGOs, 'puts repressive governments on the international agenda,' thus raising moral consciousness in opposition to norm-violating governments through transnational pressure (Risse, 
2000: 204). The primary strength that NGOs have is that they appeal to moral principle rather than to political interest (Clark, 2001: 36). Of course it is an ongoing challenge for NGOs not to become tainted by the appearance or reality of being motivated by interest rather than principle, which points to the more general range of questions about the legitimacy and accountability of the institutions of civil society (see, for example, Carothers, 1999-2000: Bond, 2000). The institutions of transnational civil society may not have to meet the same standards of accountability as governments to their constituents or corporations to their shareholders, but this does not mean they escape accountability, since their reputations are perhaps their most vital assets. In seeking to play the role of 'the conscience of humanity,' as UN Secretary-General Kofi Annan has referred to NGOs, these institutions must struggle to articulate norms that are understood to be based on general moral principle, rather than sectarian interests.

In much of the literature on 'the moral economy,' the term tends to be invoked in discussions of those who have been or are being deprived of social justice. It was used famously by Edward Thompson in his 1971 historical essay 'The Moral Economy of the English Crowd in the Eighteenth Century,' a detailed account of what precipitated 18thcentury 'food riots,' and how they were manifested (Thompson, 1971). During periods of grain shortages, some farmers, grain merchants, and bread bakers would raise their prices in order to stem lost revenue, the result of which was to make these staples unaffordable by peasants and the proto-working class. One response that occurred periodically was the public expression of outrage at the callousness of the sellers for their willingness to extract the same levels of profit during hard times, despite the suffering it caused, especially in a context in which such market practices were quite unfamiliar:

It is not easy for us to conceive that there may have been a time, within a smaller and more integrated community, when it appeared to be 'unnatural' that any man should profit from the necessities of others, and when it was assumed that, in time of dearth, prices of 'necessities' should remain at a customary level, even though there might be less all around. (Thompson, 1971: 131-2)

The riots were responses to a variety of what were then viewed as 'illegitimate practices in marketing, milling, baking, etc.' among the sellers of grain and bread. 'This in its turn was grounded upon a consistent traditional view of social norms and obligations, of the proper economic functions of several parties within the community, which, taken together, can be said to constitute the moral economy of the poor' 
(Thompson, 1971: 79). In essence, Thompson writes, it was a moral economy that guided the expectations of 'the English crowd,' and fostered the outrage that was manifested in 'food riots.' But Thompson makes it clear that these riots were not 'rebellions of the belly,' that is, they were not irrational expressions of hunger, but rather they were reactions against the violation of a set of customs - a moral economy that shaped common expectations of what was socially just, and thus about the principles that should guide a community (Thompson, 1971: 77; see also Polanyi, 1944). Over time, the moral economy of the English peasantry and proto-working class lost its foundation due to the transformation from local economies to a national economic system. With the shift from local political economies to a national political economy, including a price system that gradually became less sensitive to local variations of supply and demand, the old moral economy lost its sway, as 'the new political economy was disinfested of intrusive moral imperatives' (Thompson, 1971: 90).

Twenty years later, Thompson (1991) expressed ambivalence about the uses to which his study had been put in subsequent work by others. While recognizing the great influence that his essay had had for a generation of historians and scholars in other disciplines, he was concerned about what he considered to be misuses of the concept, reminding the reader that his primary aim in 1971 was to demonstrate how the 18th-century 'food riots' were a rational response to the social dislocation that had resulted from the emergence of a new politicaleconomic order in England. This response to the new economy was grounded in widely understood and accepted custom and tradition of that time and place. Thompson endeavored to explain a rational response to the violation of social norms that governed a minimally dignified and humanly tolerable life for the working poor of the time. Thompson's conception of a moral economy helps to explain the rational basis for moral outrage among a citizenry who had grown accustomed to a set of social norms that, while not ideal, enabled them to live with a modicum of dignity. The context of outrage described in Thompson's analysis is centered on disruption caused by the great transformation from local economies to a cold and impersonal nationalizing economy and price system. Although it is tempting to conflate explanations about the moral economy with the practice of moralizing in order to distinguish a moral from an immoral economy, that is not what Thompson seemed to have in mind. ${ }^{3}$ He saw in the food riots of 18th-century England a struggle over human dignity and the minimal requirements of a decent life, if not a good life. His point did not seem to be that the social order 
of the time was a morally just one. Rather, it was a social order that had a particular embedded moral code, for better or worse.

It is not difficult to see the relevance of Thompson's analysis for understanding the great transformation taking place today, as national economies cede ever greater measures of power to an increasingly globalizing system of trade and investment. The growing litany of more or less successful efforts to disrupt, bring bad publicity to, and even shut down high-powered gatherings of the world's economic and political elite over the past several years has been testimony to the capacity of a very broad spectrum of cultural, social, political, and economic interests to join forces in efforts to be heard in protest against the actions of those responsible for producing grave environmental damage that threatens all forms of life, and for promoting and underwriting the costs of egregious and systematic violations of human rights, including unjust imprisonment, torture, assassination, and genocide.

Although Thompson gave new life and meaning to the term 'moral economy,' it is not a concept of his invention, nor is it one that necessarily should be applied strictly within the parameters that he found useful in his own work (see, for example, Perry, 1909; Murphy, 1993; Booth, 1993, 1994; Powelson, 1998; Sayer, 2000). In a view of the idea of a moral economy that bears very little resemblance to that of Thompson, William James Booth looks instead into the ancient origins of the concept. Booth begins by asking how a moral economy can and ought to be seen as the basis upon which the Aristotelian conception of the good life is built. The classical conception of the good life shunned the marketplace, because a life that is centered around the market was considered constrained by a lack of freedom to pursue one's praxis. Indeed, Booth notes, Aristotle would have denied citizenship to persons who lacked the leisure time that was needed to pursue citizenship (Booth, 1994: 221-2, 228). ${ }^{4}$ Of course, the ability to be a citizen in the Aristotelian sense, and to enjoy the concept of the good life that was valued in this context, rested on unequal social relations, as it was not only natural but desirable for the master of the oikos (the ancient household) to rely on a moral economy that was geared towards the maintenance of his freedom, so that he could exercise his praxis in the polis (Booth, 1994; see also Booth, 1993).

Booth does not romanticize this vision of a moral economy, but he does seek to define for it one core virtue that is lost in our present world, and that is the value in having economic life, the life that pertains to the instrumental aims of sustenance and survival, be subordinate to, rather than the driving force behind, political life, or the life of freedom as the 
ancients defined it. What is lost in the contemporary world, he argues, is a meaningful answer to the question 'to what end?' our economic lives are geared. Not unlike Max Horkheimer, Booth laments that the marketdriven modern world forces us to organize life around survival and acquisition, eclipsing our vision of values of a higher nature (Horkheimer, 1974/1947). Reflecting on ancient republican virtue, Booth's question is the same one that modern communitarians pose in response to a proliferation of rights claims that they see devoid of organizing principles. The question of organizing principles has been a subject of concern among participants and observers reflecting on the lack of unifying vision animating the global justice movement. Rather, the movement, or perhaps more accurately the movement of movements, is one that has no center, and no hierarchy of principles. With a common target in sight - ruthless corporate globalization - these movements seem able to suspend their differences for now and join forces in a broad coalition. But as Naomi Klein has observed,

Many of the key NGOs, though they may share the anarchists' ideas about democracy in theory, are themselves organized as traditional hierarchies. They are run by charismatic leaders and executive boards, while their members send them money and cheer from the sidelines. (Klein, 2000)

Given that each of these hierarchies has its own priorities, it is not unreasonable to wonder about the stability of the lines of resistance to corporate globalization. Contemporary social movements have been called into question for a number of reasons by both antagonists and self-critical protagonists. One principal question is what unites them? For example, how do we reconcile the arguably regressive motivations of nationalist labor protectionism with progressive efforts to strengthen a transnational labor movement when some of the key players are the same? ${ }^{5}$ As the two perspectives outlined above suggest, moral economic reasoning asks us to reflect not only on what causes outrage, but also what constitutes solidarity of aspiration. Much remains to be done in deciding how we relate the concept of justice to common dreams, and it is certain that the means of communication will be central to the effort.

\section{Communication and the moral economy}

Voices of opposition have raised collective consciousness about the stakes of economic globalization among ordinary citizens to a level that would never have occurred otherwise. And for that, we can appreciate the civic education that contemporary protest politics has provided to us, regardless of whether we agree with the perspectives being expressed. 
As forms of political investigation, expression, theater, and communication, the recent challenges to the unfettered consolidation of global trade, investment, and property regimes have been startling and, in some ways, unprecedented. But there is also a great deal of continuity in what these movements represent, and in the strategies they employ. What is being challenged today is the legitimacy not only of national institutions, national capital, and colonial power, but also the legitimacy of transnational governing institutions and deterritorialized capital.

In mounting challenges, today's protest movements have rapidly acquired vital tools of communication and the sophisticated capacities to use them effectively to publicize, organize, and mobilize. But more importantly, they are contributing to the setting of new standards to define the meaning of multi- and inter-cultural civic competence in this age of expanding global communication. The new transnational protest movements are seeking common cause in a global discourse about how to combat poverty, reduce ecological risk, respect the sanctity of human life, and enhance the prospects for democratic autonomy outside the scope of national authority structures. There is no doubt that the means of communication will continue to be fundamental in the efforts to build and maintain solidarity across these diverse movements.

Today's global movement for communication rights is nothing less than a centerpiece of what we know as the global justice movement. Not surprisingly, in 2005 in Porto Alegre, Brazil, the organizers of the World Social Forum included 'Communication' as one of the major sites to which considerable resources and public discussion were allocated. In the wake of the 1999 United Nations Development Program's Human Development Report, Globalization with a Human Face (UNDP, 1999), in which the global dimensions of the 'digital divide' were described as a 'grotesque gap,' communication rights of individuals and vulnerable groups have come to be of growing concern in the policy discussions and agendas of many intellectuals, NGOs and multilateral governance organizations. 6 The World Summit on the Information Society (WSIS) is a high-profile, multilateral response to such concerns, illustrating widespread awareness that the means of communication are a necessary element in fighting global poverty. In sum, the means of communication are both an instrument in contemporary global justice struggles, and these means are themselves an object of struggle, as the global movement for communication rights clearly indicates. In both sets of struggles, the means of communication are necessary, but not sufficient, to sustaining a nascent global moral economy, with all of its contradictions. 


\section{Acknowledgements}

This article was presented at the University of Colorado colloquium, 'A Fourth Rights Revolution? Communication Rights and Global Justice', April 1-3, 2005, Boulder. The author wishes to thank the following sources of funding support at the University of Colorado: the Tocqueville Center, the Keller Center for the Study of the First Amendment, and the School of Journalism and Mass Communication.

\section{Notes}

1 'Civil Society Declaration to the World Summit on the Information Society, Shaping Information Societies for Human Needs', 8 December 2003, Geneva. Available at: http://www.wsis2005.org/wsis/main_c01_02.htm

2 That is not to say communitarians have completely ignored the moral deficiencies of neoliberalism. For example, Michael Sandel briefly laments how the corrosive effects of capital flight or the disempowering consequences of economic power organized on a vast scale' were of little concern to Ronald Reagan, a president who often spoke of the virtues of family and community while simultaneously assaulting them through the promotion of unregulated enterprise (Sandel, 1996: 312-13). Yet the primary preoccupation of Sandel and other communitarians has by far been the moral deficiencies of downtrodden individuals and families, not business enterprises.

3 Thompson does discuss what in essence are two moral economies, one that conforms and the other that resists or asserts autonomous will. For example, he draws a connection between what he terms 'moral economy' and what Gramsci terms 'popular morality,' the latter of which Gramsci contrasts with 'official morality' - 'one of praxis and the other "inherited from the past and uncritically absorbed"' (1991: 10). Elsewhere, Thompson unequivocally clarifies that he intends no dichotomy between a morally pure economy of the poor, on the one hand, and an immoral market economy, on the other: 'I will refrain from mentioning those critics who have put up the fat-headed notion that there has been proposed an absolute segregation between a moral and a market economy, to save their blushes' (1991: 272).

4 It should be noted that Booth writes from the perspective of a rational choice theorist who views social structures in terms of their utility. In this case, the interests of the master of the household are the primary utility.

5 I am grateful to Vincent Mosco for the valuable exchange we had on precisely this question during our discussion at his lecture, 'Here Today, Outsourced Tomorrow: Knowledge Workers in the Global Economy,' presented at the University of Colorado, Boulder, 22 April 2005.

6 See particularly Chapter 2, 'New Technologies and the Global Race for Knowledge.'

\section{References}

Amin, Samir, Arrighi, Giovanni, Frank, Andre Gunder and Wallerstein, Immanuel (1990) Transforming the Revolution: Social Movements and the World System. New York: Monthly Review Press. 
Arrighi, Giovanni, Hopkins, Terrence K. and Wallerstein, Immanuel (1989) Antisystemic Movements. London: Verso.

Bond, Michael (2000) 'The Backlash Against NGOs', Prospect Magazine April. Available at: [http://www.globalpolicy.org/ngos/backlash.htm]

Booth, William James (1993) Households: On the Moral Architecture of the Economy. Ithaca, NY: Cornell University Press.

Booth, William James (1994) 'Household and Market: On the Origins of Moral Economic Philosophy', Review of Politics 56: 207-35.

Calabrese, Andrew (1997) 'Creative Destruction? From the Welfare State to the Global Information Society', Javnost/The Public 4(4): 7-24.

Calabrese, Andrew (1999a) 'The Welfare State, the Information Society, and the Ambivalence of Social Movements', in Andrew Calabrese and Jean-Claude Burgelman (eds) Communication, Citizenship, and Social Policy: Re-thinking the Limits of the Welfare State, pp. 259-77. Lanham, MD: Rowman \& Littlefield.

Calabrese, Andrew (1999b) 'Communication and the End of Sovereignty?', Info: The Journal of Policy, Regulation, and Strategy for Telecommunications, Information, and Media 1(4): 313-26.

Calabrese, Andrew (2004a) 'The Promise of Civil Society: A Global Movement for Communication Rights', Continuum: Journal of Media and Cultural Studies 18(3): 317-29.

Calabrese, Andrew (2004b) 'Stealth Regulation: Moral Meltdown and Political Radicalism at the Federal Communications Commission', New Media and Society 6(1): 18-25.

Calabrese, Andrew and Redal, Wendy (1995) 'Is There a US Foreign Policy in Telecommunications? Transatlantic Trade Policy as a Case Study', Telematics and Informatics 12(1): 35-56.

Carothers, Thomas (1999-2000) 'Think Again: Civil Society', Foreign Policy Magazine Winter. Available at: [http://www.globalpolicy.org/ngos/civsoc.htm]

Clark, Ann Marie (2001) Diplomacy of Conscience: Amnesty International and Changing Human Rights Norms. Princeton, NJ: Princeton University Press.

De Grieff, Pablo and Cronin, Ciaran (eds) (2002) Global Justice and Transnational Politics. Cambridge, MA: MIT Press.

De Jong, Wilma, Shaw, Martin and Stammers, Neil (eds) (2005) Global Activism, Global Media. London: Pluto Press.

DeMartino, George F. (2000) Global Economy, Global Justice. London: Routledge.

Etzioni, Amitai (1995) 'Too Many Rights, Too Few Responsibilities', in Michael Walzer (ed.) Toward A Global Civil Society, pp. 99-105. Providence, RI: Berghahn Books.

Etzioni, Amitai (ed)(1998) The Essential Communitarian Reader. Lanham, MD: Rowman \& Littlefield.

Finer, Catherine Jones (ed.) (1999) Transnational Social Policy. Oxford: Blackwell.

Glendon, Mary Ann and Blankenhorn, David (eds) (1995) Seedbeds of Virtue. New York: Madison Books.

Habermas, Jürgen (2001) The Postnational Constellation, trans. and ed. Max Pensky. Cambridge, MA: MIT Press.

Horkheimer, Max (1974/1947) 'Means and Ends', in Eclipse of Reason. NY: Continuum.

Klein, Naomi (2000) 'The Vision Thing', The Nation 10 July. Available at www.thenation.com.

Marshall, T.H. (1950) 'Citizenship and Social Class', in Citizenship and Social Class and Other Essays, pp. 1-85. Cambridge: Cambridge University Press. 
Mayer, Caroline E. (1983) 'FCC Chief's Fears: Fowler Sees Threat in Regulation', Washington Post 6 February: K1.

Mead, Lawrence M. (1986) Beyond Entitlement: The Social Obligations of Citizenship. New York: Free Press.

Mulhall, Stephen and Swift, Adam (1996) Liberals and Communitarians, 2nd edn. Oxford: Blackwell.

Murphy, James Bernard (1993) The Moral Economy of Labor: Aristotelian Themes in Economic Theory. New Haven, CT: Yale University Press.

Perry, Ralph Barton (1909) The Moral Economy. New York: Charles Scribner's Sons.

Polanyi, Karl (1944) The Great Transformation. New York: Farrar and Rinehart.

Powelson, John P. (1998) The Moral Economy. Ann Arbor, MI: University of Michigan Press.

Roach, Colleen (1997) 'The Western World and the NWICO', in Peter Golding and Phil Harris (eds) Beyond Cultural Imperialism: Globalization, Communication and the New International Order. London: Sage.

Risse, Thomas (2000) 'The Power of Norms versus the Norms of Power: Transnational Civil Society and Human Rights', in Ann M. Florini (ed.) The Third Force: The Rise of Transnational Civil Society, pp. 177-209. Washington, DC: The Carnegie Endowment for International Peace.

Sandel, Michael J. (1996) Democracy's Discontent: America in Search of a Public Philosophy. Cambridge, MA: Harvard.

Sayer, Andrew (2000) 'Moral Economy and Political Economy', Studies in Political Economy 61, Spring: 79-103.

Schultz, George (1984) 'Letter from US Secretary of State George Schultz to UNESCO Director-General Amadou-Mahtar M'Bow, announcing the decision of the US government to withdraw its membership from UNESCO (28 December 1983)', Journal of Communication 34(4): 82, 84.

Skeel, David A. Jr (2001) 'Shaming in Corporate Law', University of Pennsylvania Law Review June: 1811-68.

Teeple, Gary (2000) Globalization and the Decline of Social Reform: Into the Twenty-First Century, 2nd edn. Aurora, ON, Canada: Garamond.

Thompson, E.P. (1971) 'The Moral Economy of the English Crowd in the Eighteenth Century', Past and Present 50: 76-136.

Thompson, E.P. (1991) 'The Moral Economy Reviewed', in Customs in Common, pp. 259-351. New York: New Press.

Walker, Samuel (1998) The Rights Revolution: Rights and Community in Modern America. New York

United Nations Development Program (UNDP) (1999) Globalization with a Human Face. The 1999 UNDP Human Development Report. Available at: http://www.undp. org/hdro/99.htm.

\section{Biographical note}

Andrew Calabrese is a professor of media studies at the University of Colorado in Boulder. He has published many research articles on communication politics and policy, and edited Information Society and Civil Society: Contemporary Perspectives on the Changing World Order (Purdue University Press, 1994, with 
Slavko Splichal and Colin Sparks), Communication, Citizenship and Social Policy: Rethinking the Limits of the Welfare State (Rowman \& Littlefield, 1999, with JeanClaude Burgelman), and Toward a Political Economy of Culture: Capitalism and Communication in the 21st Century (Rowman \& Littlefield, 2004, with Colin Sparks). He won the 1991 Donald McGannon Award for Social and Ethical Relevance in Communication Policy Research, and he was a Fulbright scholar in Slovenia in 1998. He edits a book series called Critical Media Studies: Institutions, Politics and Culture, for Rowman \& Littlefield Publishers, and serves on editorial boards of several research journals. He is a member of the International Council of IAMCR and a founding board member of the European Institute for Communication and Culture (EURICOM).

Address: School of Journalism and Mass Communication, University of Colorado, Campus Box 478, Boulder, CO 80309, USA.

[email: andrew.calabrese@colorado.edu] 